\title{
The Correlation Between Students'Vocabulary Mastery and Their Interest in English Toward Reading Comprehension in descriptive Text at the Second Semester of Muhammadiyah University of Metro Academic Year 2014/2015 By
}

\author{
Eva Faliyanti \\ Email: evafaliyanti1980@gmail.com
}

\begin{abstract}
Abstarct
Vocabulary is one aspects in reading comprehension. By having a lot vocabulary, the students understand in reading comprehension. The interest in English also gives effect of students mastery in English. Before the students start to read they are must be interested in English first. Reading is one of skills in English that very essential for the students, because by reading the students can get information from the text. In this research the researcher focoses on reading comprehension in descriptive text. The problems formulation in this research are; (1) How far is the students score of ability in vocabulary mastery toward reading comprehension in descriptive text? (2) How far is the students score of ability in students interest in English toward reading comprehension in descriptive text? (3) How far is the correlation between students' score of vocabulary mastery and students interest in English toward reading comprehension in descriptive text?. The objective of the research are; (1) To identify the students' score in vocabulary mastery toward reading comprehension in descriptive text. (2) To identify the students' score in students interest in English toward reading comprehension in descriptive text. (3) To find out how far the correlation between students' score of vocabulary mastery and students interest in English toward reading compregension in descritive text.

The research was conducted at the second semester of Muhammadiyah University Students in Academic Year 2014/2015. The population of this research was 127 students. The researcher used cluster ramdom sampling in taking sample. In collecting the data the researcher used test and questionnarie, namely vocabulary mastery and reading comprehension in descriptive text. In questionnarie used to students interest in English and in analyzing the data, the researcher used Product Moment Formula.

After analyzing the data by using the correlation product moment and Regression Linearity Test, the researcher gets the result of based on the calculation, it is found that: 1) of $r=0,45$ ( $\mathrm{X}_{1}$ and $\left.\mathrm{Y}\right)$. 2) 0,61 ( $\mathrm{X}_{2}$ and $\left.\mathrm{Y}\right)$. 3) 0,98 ( $\mathrm{X}_{1}, \mathrm{X}_{2}$ and $\mathrm{Y}$ ). The hypothesis can be accepted because $t_{\text {ratio }}=4,3$ and $t_{\text {daf }}=2,04$. It means that $t_{r a t i o}>t_{d a f}$ and $\mathrm{Ha}$ is accepted because there is positif and significant correlation between students' vocabulary mastery and their interest in English toward reading comprehension in descriptive text.
\end{abstract}

Key words: Students' Vocabulary Mastery and Their Interest in English Toward Reading Comprehension In descriptive Text. 


\section{Introduction}

\section{Problem Background}

English is regarded as foreign language in Indonesia which formally taught in Indonesia from the primary schools up to university. Therefore, for the students must be able master English. It has four basic language skills. They are listening, speaking, reading, and writing. Beside those skills, there are some components in English namely vocabulary, structure, phonetic/phonology, etc.

Vocabulary is one of the problems faced by English language. When they have a lot of vocabulary they can understand the English the easily, especially in reading. The interest in English also gives effect of students mastery in English. Before the students start to read they are must be interested in English first. Because when they do not have interesting in English they difficult to master it. Sometimes, the students are lazy to read. Conseqently, they are getting difficulty to comprehend the text. The students in the second semester have difficulty to understand the text. Because their vocabulary and interest in reading are still low. This is the first time they have the subject specially in reading text. They must focus for this subject. The researcher makes reading texts in which there are some interesting images, for example in the descriptive text. In descriptive text the picture can explain something more interesting and easy to understand.

Based on pra-survey the researcher found that There are $24 \%, 7$ students who include in low criteria. There are 50\%,16 students who include in high criteria. And they are $26 \%, 8$ students who include in midle criteria. The students are expected to be able to increase their ability especially in vocabulary mastery and their interest in English in order to master reading comprehension in descriptive text well.

\section{Conceptual Definition}

\section{Students' Vocabulary Mastery}

Handayani (2007:1) says that vocabulary is knowledge of word and meaning. The knowledge and word often make the distinction between oral and vocabulary or 
the word recognize and use in reading and writing. Language consists of a number of words formed. When speak and write uses word. Most of our thinking is in word. Most of communication primarily based on our knowledge of the words.

In other word it can be said that vocabulary is essensial to master. When students want to comprehend the texts, it needs vocabulary. Vocabulary is very important to learn because it is first thing which mastered by learner. Yang Zhihong (2000:38) says "Words are the basic unit of language from supports it without vocabulary, one cannot communicate to the effectively or express idea". It means that without having vocabulary mastery, people can not master English. Vocabulary plays a prominent role in mastering English

\section{Students Interest in English}

Sardiman (2004: 73) said that the highest study interest can make easier students to get purpose of learning. Another factor influencing learning achievement is interest in learning. Interest can be defined as the driving force of the inside and on the subject to perform certain activities in achieving the goal. The intent of the statement is the motivation (interest) will cause a change in the existing energy within the individual, so that will be associated with symptoms of psychiatric or psychological problems someone, feelings and emotions, to then act or do something.

\section{Reading Comprehension}

According to Pakhare (2007:173), reading comprehension can be defined level of understanding of a message or text. For formal reading rates (around 200-220 words per minutes) an acceptable level of comprehension is above 75\%)

Based on the definition above, it can be said that reading comprehension is the level of passage or text understanding while reading. Comprehension occurs when readers are able to understand, remember, retell and discuss with others about what they have read. Reading comprehension requires motivation, mental framwork for holding ideas, concentration and good study techniques. Good readers employ many strategies as they trying to comprehend what they are reading. 


\section{Descriptive Text}

According to Zumarkhin (2005:5), descriptive text is to describe something, sch us people, thing and animal. Descriptive text is very important for us when the students want to descriptive about smoething. In addition Kane (2000:352) Descriptive text is the description and identification of the structure text such us person and thing.

Meanwhile, Pardiyono (2007:33) states that descriptive text is a type of written text. Which has specifik function to give description about an object (human or non human)

\section{METHODS}

Research design in this research is correlation design, and the reseacher uses quantitave method. The research conducted this research at the second semester of muhammadiyah university students and the research takes 35 students as samples, then to get the data the research uses test. The test is reading comprehension. From a group of students who may give the data on three different variables without giving any treatment and control. The researcher concludes that the research design in this research is correlation desaign. The researcher only gives the test and questionnaries to the students without having treatment.

\section{FINDINGS}

\section{Analysis of Students Vocabulary Mastery}

The vocabulary mastery test was administered in order to look the students' score of students' vocabulary mastery test. The researcher gives 30 items test and the total of the sample were 35 students. Based on the result of the test, the highest score was 93 and the lowest score was 50 . The total of all students were 2423 and the average was 69.

\section{Analysis of Students Interest in English}


The interest in English test was administered in order to look the students' score of students interest in English questionnarie. The result of the test can be seen in appendix 36. The researcher gives 20 items questionnarie and the total of the sample were 35 students. Based on the result of the test, the highest score was 98 and the lowest score is 51 . The total of all students were 2554 and the average was 73.

\section{Analysis of Reading Comprehension in Descriptive Text}

The reading comprehension in descriptive text test was administered in order to look the students' score of reading comprehension in descriptive text. The researcher gives 30 items and the total of the sample were 35 students. Based on the result of the test, the highest score was 90 and the lowest score was 55. The total of all students was 2467 and the average is 70 .

\section{The Correlation of Students' Vocabulary Mastery (X1) and Raeding Comprehension in}

Descriptive Text (Y)

The researcher knows whether there is positive and significant correlation between students' vocabulary mastery and reading comprehension in descriptive text or not, both variables were calculated by using the formula of person product moment coefficient correlation.

Based on the calculation above found that $r=0,97$. It means that the correlation between students' vocabulary mastery and reading comprehension in descriptive text is very high based on the table interpretation value $r$.

\section{The Correlation of Students Interest in English (X2) and Reading}

\section{Comprehension in Descriptive Text(Y)}

The researcher knows whether there is positive and significant correlation between students interest in English and reading comprehension in descriptive text or not, both variable were calculated by using the formula of person product moment coefficient correlation. 
Based on the calculation above, the researcher found that $r=0,97$. It means that the correlation between students interest in English and reading comprehension in descriptive text is very high based on the table interpretation value $r$.

\section{The Correlation of Students' Vocabulary Mastery(X1) and Students Interest in English(X2)}

The researcher knows whether there is positive and significant correlation between students' vocabulary mastery and students interest in English or not, both variable were calculated by using the formula of person product moment coefficient correlation.

Based on the calculation above, the researcher found that $r=0,97$. It means that the correlation between students' vocabulary mastery and students interest in English is very high based on the table interpretation value $r$.

\section{Multiple Linearity Test}

To know whether the multiple linear regression that gotten by the researcher is meaningful or not to make conclusion about the correlation between students' vocabulary mastery, interest in English and reading comprehension in descriptive text.

The criteria linearity test is reject $H_{o} f_{\text {ratio }} \geq f_{\text {daf. }}$. Based on the calculation, the researcher found the value of $f_{\text {ratio }}$ and $f_{\text {daf }}$. the researcher found the value in $f_{\text {ratio }}=$ 136,1 and the value $f_{\text {daf }}=3,3$. It means that $f_{\text {ratio }} \geq f_{\text {daf. So, the researcher }}$ concluded that $\mathrm{H}_{\mathrm{o}}$ was rejected and $\mathrm{H}_{1}$ was accepted. So, the multiple linear regression were meaningful to make conclusion.

\section{The Result of Significant Correlation Between Students' Vocabulary Mastery (X1) and Reading Comprehension in Descriptive Text (Y)}

The researcher found the significant correlation between students' vocabulary mastery (X1) and reading comprehension in descriptive text (Y) by calculating the value of $r_{y 12}$ using the formula as follow :

$$
r_{y 1.2}=\frac{r_{y 1}-r_{y 2} \cdot r_{12}}{\sqrt{\left(1-r_{y 2}{ }^{2}\right)\left(1-r_{12}{ }^{2}\right)}}
$$


After calculating the data, the researcher got score for the significant correlation between $X_{1}$ and $Y$. The significant correlation value was 0,45 . Based on the $r$ criteria, the significant correlation between $\mathrm{X}_{1}$ and $\mathrm{Y}$ was fair significant.

The Result of Significant Correlation Between Students Interest in English (X2) and Reading Comprehension in Descriptive Text (Y)

The researcher found the significant correlation between students interest in English (X2) and reading comprehension in descriptive text (Y) by calculating the value of $r_{y 21}$ using the formula as follow, after calculating the data, the researcher got score for the significant correlation between $\mathrm{X}_{2}$ and $\mathrm{Y}$. The significant correlation value was 0,61 . Based on the $r$ criteria, the significant correlation between $\mathrm{X}_{2}$ and $\mathrm{Y}$ was high significant.

$$
r_{y 2.1}=\frac{r_{y 2}-r_{y 1} \cdot r_{12}}{\sqrt{\left(1-{r_{y 1}}^{2}\right)\left(1-{r_{12}}^{2}\right)}}
$$

The Result of Significant Correlation Between Students' Vocabulary Mastery (X1), Students Interest in English (X2) and Reading Comprehension in Descriptive Text (Y)

The researcher found the significant correlation between students' vocabulary mastery (X1), students interest in English (X2) and reading comprehension in descriptive text $(\mathrm{Y})$ by calculating the value of $\mathrm{r}_{\mathrm{y} 21}$ using the formula as follow :

$$
R^{2}=\frac{\text { JKreg }}{\sum y^{2}}
$$

After found the data of students' vocabulary mastery (X1), students interest in English (X2) and reading comprehension in descriptive text (Y), the research found the score for the significant correlation between $\mathrm{X} 1, \mathrm{X} 2$, and $\mathrm{Y}$. the researcher got the significant correlation value was 0,98 . Based on the criteria $r$, the significant correlation $\mathrm{X} 1, \mathrm{X} 2$ and $\mathrm{Y}$ was very high.

\section{Coefficient Correlation Test}

The Partial Coefficient Correlation Between Students' Vocabulary Mastery(X1) and Reading Comprehension in Descriptive Text (Y) 
The criteria of the test is Ho if $t_{\text {ratio }} \geq t_{\text {daf, }}$ with the probability $\alpha=0,05$. Based on the calculating the researcher found the value of $t_{\text {ratio }}=4,3$ and the value of the $t_{\text {daf }}$ with degree of freedom (df) $n-k-1=2,04$. So, the researcher concludes that Ho was rejected and $\mathrm{H}_{1}$ was accepted.

The partial Coefficient Correlation Between Students Interest in English $\left(\mathbf{X}_{2}\right)$ and reading comprehension in Descriptive Text $(\mathbf{Y})$

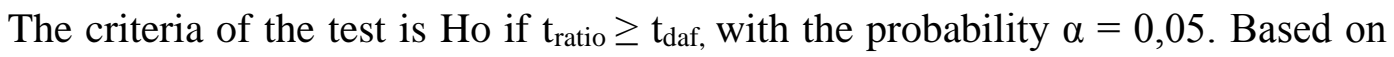
the calculating the researcher found the value of $t_{\text {ratio }}=4,3$ and the value of the $t_{\text {daf }}$ with degree of freedom $(\mathrm{df}) \mathrm{n}-\mathrm{k}-1=2,04$. So , the researcher concludes that Ho was rejected and $\mathrm{H}_{1}$ was accepted.

\section{Multiple Coefficient Correlation Between Students' Vocabulary Mastery $\left(\mathbf{X}_{1}\right)$, Students Interest in English $\left(\mathbf{X}_{2}\right)$ and Reading Comprehension in Descriptive Text (Y)}

Based on the calculating the data, the researcher found the value of $f_{\text {ratio }}$ is 261,3 and $f_{\text {daf }} 3,30$. So, the researcher result that $f_{\text {ratio }} \geq f_{\text {daf }}$. based on the test criteria, Ho was rejected and $\mathrm{H}_{1}$ was accepted.

\section{Hypothesis Test}

The significant correlation between the students score in vocabulary mastery toward reading comprehension in descriptive text

Based on the calculation above, the researcher found that the correlation between the students score in vocabulary mastery toward reading comprehension in descriptive text was 0,45 . Based on the $r$ criteria, the significant correlation between students' vocabulary mastery toward reading vocabulary mastery was fair significant correlation.

The significant correlation between students' vocabulary mastery, students interest in English and reading comprehension in descriptive text 
Based on the calculation above, the researcher found the score for the significant correlation between students' vocabulary mastery and students interest in English toward reading comprehension in descriptive text, the researcher got the significant correlation value was 0,98 . Based on the criteria $r$, the significant correlation students' vocabulary mastery and students interest in English toward reading comprehension in descriptive text was very high.

\section{Conclusion}

Based on the research objective and result of analysis data in the second semester students of Muhammadiyah University Academic Years of 2014/2015, the researcher draws conclusion as follows:

1. The result of students' score of ability in vocabulary mastery shows significant correlation by increasing score of the students in the research was high score. The students got score 80 in try out and 83 in test. Its means that the students can enough to identifying the vocabulary of family, supermarket and school.

2. The result of students' score of interest in English shows significant correlation by increasing score of the students in the research was high score. The students 90 score in this test. Its means that the students can enough to identifying the follow the material well, response about English, lesson Identify the students effort, identify the students pleasure.

3. The result of students' score of reading comprehension in descriptive text shows significant correlation by increasing score of the students in the research was high score. The students got score 77 in try out and 90 in test. Its means that the students can enough to identifying the identify the main idea, purpose of the text, characteristics of description, characters, generic structure, tense, pronoun, antonym, synonym.

4. The correlation between students' score of vocabulary mastery and students interest in English toward reading comprehension in descriptive text in hypothesis is positive and significant. The statement is supported by result of finding that $r_{\text {count }}$ is 8 that $r_{\text {table }} 3,3$ on the significant level of 0,05 . The value of $r_{\text {count }}$ was 
Premise Journal Vol 4 No I April 2015 ISSN: 2442-482x (cetak) ISSN: 977244248003 (electronic)

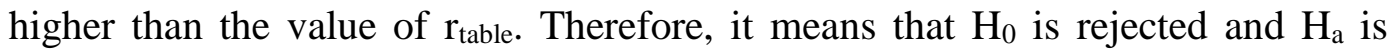
accepted $\mu_{1} \neq \mu_{2}$ (there is any correlation).

Based on the calculating in the previous chapter, the researcher conclud that the correlation between students' vocabulary mastery and their interest in English toward reading comprehension in descriptive test is any positive and significant correlation. It mean that, by the result of hypothesis of Ho is rejected and $\mathrm{Ha}$ is accepted. 


\section{References}

Ahmad, Jazim.(2011). Statisti. Metro. FKIP-UMM.

Arifin Zainal. (2012). Evaluasi Pembelajaran. PT Remaja Rosdakarya: Bandung Arikunto, Suharsimi.(2013).Prosedur Penelitian suatu pendekatan praktek. Yogyakarta: Rineka Cipta. ,(2010). Prosedur Penelitian. Yogyakarta: Rineka Cipta.

Bima. (2005:15). Definition of Descriptive Text In English. New York: Irvington

Blachowicz and Ogle (2008). Reading comprehension strategies for independent learners. New York : The Guilford press.

Crow and Crow. (2000:55). Motivasi Belajar Bahasa I. .Yogyakarta: Rake Press

Devi Normalia(2013). Correlation Between The Students' Vocabulary Mastery And Reading Comprehension Of Descriptive Text At The Second Semester Of SMA N 1 Kibang East Lampung Academic Year 2012/2013. Metro: Universitas Muhammadiyah Meto

Donald Sardiman,(2004).Interaksi dan Motivasi Belajar Mengajar. PT Raja. Jakarta: Gravindo Persada.

Handayani.(2007).Look Ahead An English.Jakarta:Erlangga.

Harris. (1969). Oxford Advenced Learner's Dictionary. Oxford University Press: New York

Hornby. (2002). Vocabulary and Language Teaching . London: Longman.

Kane. (2000). Definition of descriptive text: New York: The Guilford Paess.

Lems, Kristin.,Miller, Leah D., Soro, Tenena M (2010). Teaching Reading to English Language Learners: Insights from linguistics. New York: The Guilford press

Mahfudh Salahudin. (2000). Pengantar Psikologi Pendidikan. Surabaya : Bina Ilmu

Margono S. (1997). Metode Penelitian pendidikan. Jakarta: Rineka Cipta . (2010). Metode Penelitian pendidikan. Jakarta: Rineka Cipta

Nazir Moh. (1999). Metode Penelitian. Jakarta: Ghalia Indonesia 
Nuttal. (2003).The Definition of Reading. http/www.definitionofreading.com. Accessed on May 25th.

Pakhare. (2007). Reading Comprehension Strategies. New York: The Guilford Press

Pardiyono. (2007). Pasti Bisa! Teaching Genre-Based Writing. Jogjakarta: Andi.

Qonita. (2013).Correlation Between The Students' Vocabularu Mastery And Their Reading Comprehension At The Eleventh Garde Of Smk Ma'arif 1 Kalirejo In 2012/2013. Metro: Universitas Muhammadiyah Metro.

Safitri Metha Anggraini (2011). Correlation Between Students' Vocabulary Mastery With Students' Interest In Learning English And Writing Ability Of The First Semester Of The Eight Grade of SMP N 2 Kota Gajah Academic Year 2011/2012. Metro: Universitas Muhammadiyah Metro.

Sanjaya, Wina. (2008). Strategi Pembelajaran Berorientasi Standar Proses Pendidikan. Jakarta: Kencana.

Sing, Yogesh Kumar (2006). Fundamental of Research Methodology and Statistics. New Delhi: New Age Internatioanl Publishers

Stone, Randi (2009). Best Practice for Teaching Reading: What Award-Winning Classroom Teachers Do. California: Corwin Press

Sugiyono. (2011). Metode Penelitian Pendidikan Pendekatan Kuantitatif, Kualitatif, dan $R \& D$. Bandung : Alfabeta.

Sukardi. (2003). Metode Penelitian Pendidikan. Jakarta: Bumi Aksara

Yang Zhihong. (2000). An Introduction to The Practice of English Language Teaching. Malaysia: Longman.

Zumarkshin.(2005). Descriptive Text in English:http:/www.descriptivetext.com Accessed on May 25th. 